\title{
AKTIVITAS ANTIBAKTERI EKSTRAK METANOL AKAR TUMBUHAN MERUNG (Coptosapelta flavescens Korth.) TERHADAP BAKTERI Streptococcus mutans
}

\author{
Nurul Musdalifah Aprilia ${ }^{1, *}$, Wahyu Widayat ${ }^{2}$, Adam M. Ramadhan $^{1}$ \\ ${ }^{1}$ Laboratorium Penelitian dan Pengembangan Kefarmasian "Farmaka Tropis", \\ Fakultas Farmasi, Universitas Mulawarman, Samarinda, Indonesia \\ ${ }^{2}$ Laboratorium Biologi Farmasi, Fakultas Farmasi, Universitas Mulawaran, Samarinda, \\ Kalimantan Timur \\ *Email: nurulmusdalifahaprilia@yahoo.com
}

\begin{abstract}
ABSTRAK
Streptococcus mutans merupakan salah satu bakteri gram positif penyebab utama infeksi pada mulut yaitu karies gigi. Akibat tingginya prevalensi karies pada anak sehingga diperlukan alternatif dan pencarian kandidat senyawa antibakteri baru. Tumbuhan merung (Coptosapelta flavescens Korth.) merupakan salah satu tumbuhan yang memiliki potensi sebagai antibakteri yang terdapat di Kabupaten Kutai Kartanegara Kalimantan Timur. Secara empiris akar tumbuhan merung dimanfaatkan oleh masyarakat Kutai untuk mengobati beberapa penyakit infeksi seperti diare, bisul, dan keputihan. Tujuan penelitian ini adalah mengetahui aktivitas antibakteri ekstrak metanol akar tumbuhan merung terhadap bakteri Streptococcus mutans. Akar tumbuhan merung diekstraksi dengan metode maserasi dengan pelarut metanol. Pengujian antibakteri ekstrak metanol akar tumbuhan merung dilakukan menggunakan metode difusi kertas cakram Kirby-Bauer dengan konsentrasi uji (0.01, 0.02, $0.1,0.2,2,10) \mathrm{mg} /$ disc. Hasil pengujian aktivitas antibakteri menunjukan bahwa ekstrak metanol akar tumbuhan merung memiliki aktivitas antibakteri pada konsentrasi 0.02-10 $\mathrm{mg} /$ disc yang ditunjukkan dengan terbentuknya zona bening disekitar kertas cakram. Aktivitas antibakteri ekstrak metanol akar tumbuhan merung dimulai pada konsentrasi 0.02 $\mathrm{mg} /$ disc $(7.61 \mathrm{~mm})$ dan dengan zona bening terbesar ditunjukkan pada konsentrasi 10 $\mathrm{mg} /$ disc $(20.60 \mathrm{~mm})$. Hasil identifikasi golongan metabolit sekunder menunjukkan bahwa ekstrak metanol akar tumbuhan merung terdapat golongan metabolit sekunder flavonoid, fenol, tanin, dan antrakuinon. Senyawa turunan fenolik tersebut telah banyak dilaporkan memiliki aktivitas sebagai antibakteri.
\end{abstract}

Kata Kunci: Akar merung, Antibakteri, Streptococcus mutans

DOI: https://doi.org/10.25026/mpc.v6i1.277

\section{PENDAHULUAN}

Karies gigi merupakan penyakit infeksi umum yang sering terjadi dikalangan masyarakat. Karies gigi merupakan penyakit gigi terlokalisir yang merusak jaringan keras gigi, terbentuk dari akumulasi plak pada permukaan gigi dan aktifitas biomekanis kumpulan mikroorganisme kompleks. ${ }^{1}$ Streptococcus mutans merupakan bakteri 
anaerob fakultatif gram positif dikenal dapat menghasilkan asam laktat sebagai bagian dari hasil metabolisme yang berguna untuk kehidupan bakteri tersebut. Streptococcus mutans memiliki kemampuan untuk mengikat sukrosa pada permukaan gigi dengan pembentukan glukan tidak larut air dan polisakarida yang membantu dalam mengikat bakteri pada gigi. Streptococcus mutans dapat menurunkan atau mempertahankan $\mathrm{pH}$ mulut pada nilai wajar asam, yang menyebabkan kondisi yang menguntungkan untuk metabolismenya sendiri dan tidak menguntungkan bagi spesies lain yang hidup berdampingan. Penurunan $\mathrm{pH}$ yang disebabkan oleh Streptoccocus mutans dapat memfermentasi gula menjadi asam. Asam ini menempel pada email gigi yang menyebabkan terjadinya demineralisasi jaringan pada gigi dan kavitas pada gigi. ${ }^{2}$

Berdasarkan data hasil Survei Kesehatan Rumah Tangga (SKRT) tahun 2010 oleh Departemen Kesehatan RI menunjukkan bahwa $63 \%$ penduduk Indonesia menderita penyakit gigi dan mulut meliputi karies gigi dan penyakit jaringan pendukung gigi. ${ }^{3}$ Riset Kesehatan Dasar (RISKESDAS) Nasional tahun 2013 melaporkan bahwa indeks DMF-T di Indonesia mencapai 4,6 dengan nilai D-T (Decay Tooth) karies dan belum diobati 1,6, M-T (Missing Tooth) hilang atau bekas pencabutan 2,9, F-T (Filled Tooth) ditambal $0,08 .^{4}$

Salah satu upaya dalam pencegahan karies gigi adalah dengan pemanfaatan tumbuhan yang mengandung senyawa antibakteri. Tumbuhan merung (Coptosapelta flavescens Korth.) merupakan salah satu tumbuhan yang memiliki potensi sebagai antibakteri yang terdapat di Kabupaten Kutai Kartanegara Kalimantan Timur. Tumbuhan merung merupakan tumbuhan berupa semak mendaki di sekitar hutan hujan dan di tepi sungai Asia pasifik. Tumbuhan merung memiliki batang bulat berkayu berwarna hijau, daun berbentuk bulat telur dengan ujung daun meruncing, tulang daun menyirip dan permukaan daun berbulu. Sedangkan akarnya membulat seperti bonggol dan berkayu berwarna coklat kekuningan. Aroma dari batang, daun, dan akar merung sangat khas dan menyengat. Secara empiris akar tumbuhan merung dimanfaatkan oleh masyarakat Kutai untuk mengobati beberapa penyakit infeksi seperti diare, bisul, dan keputihan. Penelitian sebelumnya menunjukan bahwa ekstrak metanol akar tumbuhan merung menunjukkan aktivitas antibakteri terhadap Escherichia coli dan Staphylococcus aureus pada konsentrasi $10 \mathrm{mg} /$ disc dengan diameter zona hambat masing-masing 19,06 mm dan 20,03 mm. ${ }^{5}$ Kandungan metabolit sekunder yang terdapat pada akar tumbuhan merung antara lain flavonoid, fenol, tanin, dan antrakuinon. Senyawa-senyawa metabolit sekunder tersebut diketahui memiliki berbagai mekanisme kerja sebagai antibakteri.

Berdasarkan uraian diatas, perlu dilakukan penelitian yang bertujuan untuk mengetahui aktivitas antibakteri dan konsentrasi terbaik ekstrak metanol akar tumbuhan merung terhadap bakteri Streptococcus mutans. Sehingga akar tumbuhan merung dapat dimanfaatkan sebagai aplikasi dalam bidang kedokteran gigi dan dapat mengurangi angka kejadian karies gigi.

\section{METODE PENELITIAN}

Penelitian ini merupakan penelitian eksperimental laboratoris murni dengan rancangan penelitian post test only controlled group design.
Alat
Alat-alat penelitian yang digunakan dalam penelitian ini adalah cawan petri, tabung reaksi, erlenmeyer, gelas kimia, labu ukur, batang pengaduk, toples kaca, lampu spiritus, pipet ukur, pipet tetes, mikropipet, spoid, spatula, pinset, ose bulat, rak tabung reaksi, neraca analitik, jangka sorong, rotary 
evaporator, desikator, hot plate, autoclave, refrigerator, laminar air flow (LAF), inkubator, dan colony counter.

\section{Bahan}

Bahan-bahan penelitian yang digunakan dalam penelitian ini adalah akar tumbuhan merung yang diperoleh dari desa Tanjung Batu Kabupaten Kutai Kartanegara Kalimantan Timur, biakan murni bakteri Streptococcus mutans yang diperoleh dari Laboratorium Biologi Farmasi Fakultas Farmasi Universitas Mulawarman, metanol, kertas cakram (paper disc), aluminium foil, tisu, kapas, kasa, alkohol, spiritus, $\mathrm{NaCl} 0,9 \%$, aquadest, medium Nutrient Agar (NA), larutan standar Mc Farland, $\mathrm{AlCl}_{3}, \mathrm{FeCl}_{3}$, serbuk $\mathrm{Mg}, \mathrm{HCl}$, pereaksi dragendorf, pereaksi meyer, pereaksi liebermann burchard (LB), kloroform, asam asetat anhidrat, $\mathrm{H}_{2} \mathrm{SO}_{4}$.

\section{Persiapan Sampel}

Akar tumbuhan merung yang telah diperoleh disortasi kemudian dicuci bersih dengan air mengalir, dibersihkan dan ditimbang beratnya, lalu dipotong kecil-kecil dan dikeringkan anginkan pada suhu ruang dan terhindar dari sinar matahari langsung dan disortasi kembali hingga diperoleh sampel kering akar tumbuhan merung kemudian ditimbang beratnya sebesar $1,2 \mathrm{~kg}$.

\section{Ekstraksi Sampel}

Sampel kering akar tumbuhan merung sebanyak $1,2 \mathrm{~kg}$ dimasukkan ke dalam toples kaca dan ditambahkan pelarut metanol hingga terendam seluruhnya. Kemudian diaduk simplisia dengan batang pengaduk dan dilakukan perendaman selama dua hari dengan mengganti pelarut setiap $2 \times 24$ jam. hingga pelarut menjadi bening. Filtrat yang diperoleh disaring dengan kertas saring dan dipekatkan dengan rotary evaporator pada suhu $45^{\circ} \mathrm{C}$ sehingga diperoleh ekstrak kental akar tumbuhan merung. Kemudian ekstrak kental dimasukkan ke dalam wadah kaca dan dikering anginkan hingga diperoleh ekstrak kering dan ditimbang beratnya sebesar 182 gram.

\section{Pengujian Fitokimia}

Uji Alkaloid

Sebanyak $0,5 \quad \mathrm{~g} \quad$ ekstrak ditambahkan $1 \mathrm{~mL}$ asam klorida $2 \mathrm{~N}$ dan $9 \mathrm{~mL}$ air, dipanaskan diatas penangas air selama 2 menit, didinginkan dan disaring. Filtrat dipindahkan masing-masing 3 tetes kedalam 2 tabung reaksi. Tabung reaksi pertama diteteskan larutan pereaksi Meyer, tabung reaksi kedua diteteskan pereaksi Dragendorf masing-masing sebanyak 2 tetes. Jika terdapat alkaloid maka akan terbentuk endapan menggumpal putih/kuning dengan pereaksi Meyer. Sedangkan dengan pereaksi Dragendorf akan terbentuk endapan kuning jingga. ${ }^{6}$

\section{Uji Flavonoid}

Ekstrak ditambahkan 0,5 g serbuk magnesium dan $\mathrm{HCl}$ 0,5 M. Flavonoid positif jika terbentuk warna merah/jingga. ${ }^{7}$

\section{Uji Fenolik}

Sebanyak $2 \mathrm{~mL}$ ekstrak dilarutkan dalam aquades $10 \mathrm{~mL}$, dipanaskan 5 menit dan disaring. Filtrat yang terbentuk ditambahkan ditambahkan 4-5 tetes $\mathrm{FeCl}_{3}$ $5 \%(\mathrm{~b} / \mathrm{v})$. Adanya fenol ditujukan dengan terbentuknya warna biru tua atau hijau kehitaman. $^{7}$

Uji Tanin

Sebanyak 0,5 g ekstrak dimaserasi dengan akuades $10 \mathrm{~mL}$ selama 15 menit dan disaring. Kemudian filtrat diencerkan dengan akuades sampai hampir tidak berwarna. Sebanyak $2 \mathrm{~mL}$ filtrat ditambahkan 2 tetes larutan $\mathrm{FeCl}_{3} 10 \%$, kemudian diamati warna yang terbentuk. Apabila terbentuknya warna biru atau hijau menunjukkan adanya tanin. ${ }^{7}$ Uji steroid dan triterpenoid 
Sebanyak $2 \mathrm{~mL}$ ekstrak ditambah dengan pereaksi Liberman-Burchard 1 mL. Jika terdapat senyawa steroid akan terjadi perubahan warna biru tua atau hijau kehitaman, dan jika terdapat senyawa triterpenoid akan terjadi perubahan warna merah atau ungu. ${ }^{8}$

\section{Uji Antrakuinon}

Sebanyak $2 \mathrm{~mL}$ ekstrak ditambah dengan $\mathrm{KOH} 10 \%$. Jika terdapat senyawa antrakuinon akan terjadi perubahan warna menjadi merah. ${ }^{9}$

\section{Uji Saponin}

Sebanyak $\quad 0,5 \quad \mathrm{~g} \quad$ ekstrak dimasukkan kedalam tabung reaksi, ditambahkan $10 \mathrm{~mL}$ air panas, didinginkan, dan dikocok kuat-kuat hingga terbentuk buih yang tetap selama tidak kurang dari 10 menit setinggi 1-10 $\mathrm{cm}$. Pada penambahan 1 tetes asam klorida $2 \mathrm{~N}$, buih tidak hilang. ${ }^{9}$

\section{Pengujian Antibakteri}

\section{Sterilisasi Alat dan Bahan}

Sterilisasi dilakukan menggunakan autoklaf pada suhu $121^{\circ} \mathrm{C}$ selama 15-20 menit. Sebelum melakukan pekerjaan di Laminar Air Flow, LAF disterilisasi dengan alkohol $70 \%$ kemudian disterilkan dengan lampu UV yang telah dinyalakan 15 menit sebelum digunakan.

\section{Pembuatan Medium}

Medium Nutrient Agar (NA) yang digunakan sebagai medium pertumbuhan bakteri dibuat dengan melarutkan sebanyak 5,25 gram NA dalam $250 \mathrm{~mL}$ aquadest, kemudian dipanaskan dan diaduk hingga larutan homogen. Kemudian disterilkan dalam autoklaf dengan suhu $121^{\circ} \mathrm{C}$ selama 20 menit.

\section{Pembuatan Kertas Cakram (paper disc)}

Pembuatan kertas cakram dilakukan dengan menyiapkan potongan kertas saring berdiameter $6 \mathrm{~mm}$ dibuat dari kertas saring Whatman, diletakkan dalam cawan petri kemudian disterilkan dalam autoklaf pada suhu $121^{\circ} \mathrm{C}$ selama 20 menit.

\section{Pembuatan Suspensi Bakteri}

Biakan bakteri yang telah diinkubasi selama 24 jam ditambahkan 9 ml larutan $\mathrm{NaCl} 0,9 \%$, kemudian dibuat larutan suspensi hingga 1:40 di dalam tabung reaksi yang telah disterilkan. Selanjutnya diukur kekeruhannya dengan menggunakan metode turbidimetri dengan standar 0,5 Mc Farland.

\section{Pembuatan larutan uji}

Pada pengujian aktivitas antibakteri menggunakan metode cakram difusi, larutan uji dibuat dengan melarutkan ekstrak menggunakan pelarut metanol dengan konsentrasi ekstrak uji yang digunakan $(0.01,0.02,0.1,0.2,2$, 10) $\mathrm{mg} /$ disc.

\section{Pengujian Aktivitas Antibakteri Ekstrak Akar Tumbuhan Merung}

Pengujian aktivitas antibakteri dari ekstrak metanol akar merung dilakukan dengan metode cakram difusi menggunakan kertas cakram. Ekstrak metanol sebagai larutan uji dan pelarut metanol sebagai kontrol negatif diteteskan sebanyak $20 \mu \mathrm{L}$ pada kertas cakram kemudian didiamkan hingga kering agar pelarutnya menguap. Medium NA sebanyak $10 \mathrm{~mL}$ dimasukkan ke dalam botol pengencer steril kemudian ditambahkan suspensi bakteri S.mutans 1:40 sebanyak $100 \mu \mathrm{L}$ dan dihomogenkan lalu dituang ke dalam cawan petri dan dibiarkan hingga medium memadat. Kertas cakram berisi ekstrak yang telah kering kemudian diletakkan diatas permukaan medium padat yang telah diinokulasikan dengan bakteri. Pengujian antibakteri dilakukan pada 5 kali pengulangan. Kemudian diinkubasi dalam keadaan posisi terbalik pada suhu $37^{\circ} \mathrm{C}$ selama 24 jam. Aktivitas antibakteri diamati berdasarkan pengukuran diameter 
terbentuknya zona bening disekeliling kertas cakram.

\section{Analisis Data}

Data analisis digunakan metode Anova satu arah menggunakan SPSS 21 dengan 6 perlakuan $(5$ perlakuan masingmasing paper disc ditetesi dengan berbagai konsentrasi ekstrak metanol dari akar tumbuhan merung, 1 perlakuan paper disc ditetesi metanol hingga menguap sebagai kontrol negatif), masing-masing perlakuan dilakukan replikasi sebanyak 5 kali.

\section{HASIL DAN PEMBAHASAN}

Sampel uji yang digunakan dalam penelitian ini yaitu akar dari tumbuhan merung (Coptosapelta flavescens Korth.) berasal dari Kabupaten Kutai Kartanegara Kalimantan Timur dengan populasi terbanyak pada terdapat pada kecamatan Tenggarong.

Ekstraksi akar tumbuhan merung dilakukan dengan metode maserasi menggunakan pelarut metanol. Metode ini dipilih karena proses pengerjaannya yang mudah, peralatan yang digunakan sederhana, serta untuk menghindari terjadinya kerusakan ataupun menurunnya aktivitas senyawa yang tidak tahan terhadap suhu tinggi, oleh karena itu dipilih metode maserasi dimana metode ini dilakukan tanpa pemanasan dan dilakukan pada suhu ruang. Prinsip ekstraksi maserasi yaitu proses difusi pelarut ke dalam sel tumbuhan yang mengandung senyawa aktif. Proses difusi tersebut mengakibatkan tekanan osmosis dalam sel menjadi berbeda dengan diluar sel sehingga senyawa yang memiliki kepolaran yang sama dengan pelarut akan terdesak keluar sel (Dean, 2009). Pelarut metanol digunakan karena merupakan pelarut polar, pelarut polar memiliki kelebihan dalam mengekstraksi komponen senyawa pada ekstrak, dapat melarutkan hampir semua metabolit sekunder yang ada pada sampel uji, baik senyawa yang bersifat polar ataupun nonpolar sehingga proses pengekstrakan dapat dilakukan dengan optimal.

Ekstrak akar merung yang diperoleh selanjutnya diidentifikasi kandungan metabolit sekunder secara kualitatif. dapat dilihat pada Gambar 1 dan Tabel 1.

Hasil analisis fitokimia secara kualitatif menunjukkan bahwa pada ekstrak metanol akar merung mengandung senyawa flavonoid, fenolik, tanin, antrakuinon. dan saponin.

Metode uji aktivitas antibakteri yang digunakan adalah metode cakram difusi. Kontrol negatif yang digunakan dalam penelitian ini adalah pelarut metanol yang diteteskan pada paper disc dan ditunggu hingga menguap hingga kering. Kontrol negatif yang digunakan adalah pelarut yang digunakan untuk membuat seri konsentrasi dari ekstrak yaitu metanol. Tujuannya adalah sebagai pembanding bahwa pelarut yang digunakan sebagai pengencer tidak mempengaruhi hasil uji antibakteri ekstrak. Hasil zona hambat kontrol negatif terhadap bakteri uji adalah $0 \mathrm{~mm}$ sehingga dapat disimpulkan metanol tidak mempengaruhi aktivitas antibakteri dari ekstrak dalam menghambat pertumbuhan bakteri ditandai dengan tidak terbentuknya zona bening. Konsentrasi ekstrak yang digunakan pada pengujian yaitu $(0.01,0.02,0.1,0.2,2,10)$ $\mathrm{mg} /$ disc.Hasil pengujian aktivitas antibakteri ekstrak metanol akar tumbuhan merung terhadap bakteri Streptococcus mutans menunjukkan adanya aktivitas penghambatan dan pembunuhan pertumbuhan bakteri uji. Hal ini dapat dilihat dari hasil pengujian yang dilakukan yaitu terbentuknya zona bening disekeliling kertas cakram yang mengandung ekstrak akar merung yang dapat dilihat pada Gambar 2.

Pengujian antibakteri dilakukan sebanyak lima replikasi. Hasil rata-rata pengukuran diameter zona hambat atau bening masing-masing konsentrasi pada setiap replikasi ekstrak metanol akar 
tumbuhan merung terhadap bakteri Streptococcus mutans dapat dilihat pada Tabel 2.
Berdasarkan data tersebut dapat dilihat diameter hambat rata-rata ekstrak metanol akar merung terhadap bakteri Streptococcus mutans pada gambar 3.

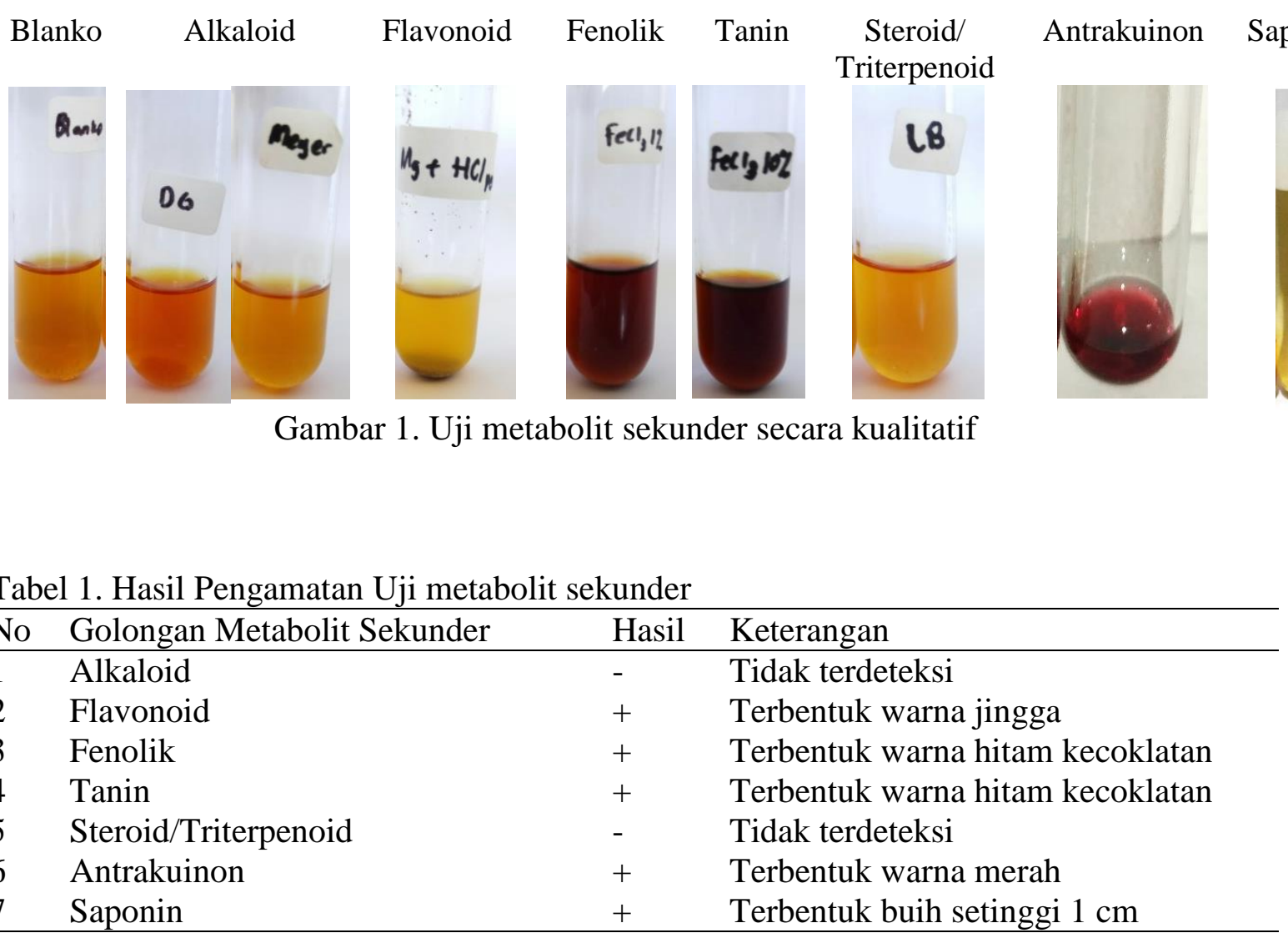

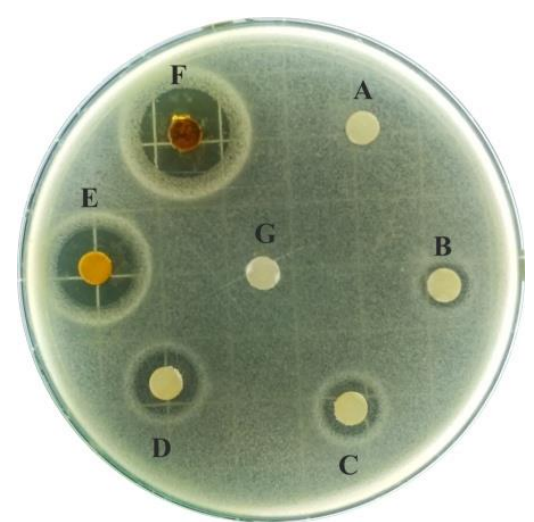

Gambar 2. Pengujian Antibakteri Terhadap Bakteri Streptococcus mutans.

Keterangan, konsentrasi bobot ekstrak pada paper disc $: \mathrm{A}=0.01 \mathrm{mg} /$ disc, $\mathrm{B}=0.02$ $\mathrm{mg} /$ disc, $\mathrm{C}=0.1 \mathrm{mg} /$ disc, $\mathrm{D}=0.2 \mathrm{mg} /$ disc, $\mathrm{E}=2 \mathrm{mg} /$ disc, $\mathrm{F}=10 \mathrm{mg} /$ disc, dan $\mathrm{G}=$ Kontrol negatif (-). 
Tabel 2. Hasil rata-rata pengukuran zona hambat atau bening ekstrak metanol akar tumbuhan merung terhadap bakteri Streptococcus mutans

\begin{tabular}{ccccccc}
\hline $\begin{array}{c}\text { Konsentrasi } \\
\text { ekstrak } \\
(\mathrm{mg} / \text { disc })\end{array}$ & $\begin{array}{c}\text { Replikasi } \\
\text { I }\end{array}$ & $\begin{array}{c}\text { Replikasi } \\
\text { II }\end{array}$ & $\begin{array}{c}\text { Replikasi } \\
\text { III }\end{array}$ & $\begin{array}{c}\text { Replikasi } \\
\text { IV }\end{array}$ & $\begin{array}{c}\text { Replikasi } \\
\text { V }\end{array}$ & d Rata-rata (mm) \\
\hline kontrol (-) & 0 & 0 & 0 & 0 & 0 & 0 \\
0.01 & 0 & 0 & 0 & 0 & 0 & 0 \\
0.02 & 8.19 & 7.17 & 7.52 & 7.74 & 7.45 & 7.61 \\
0.1 & 12.97 & 9.50 & 9.45 & 10.33 & 8.80 & 10.21 \\
0.2 & 13.83 & 10.41 & 11.06 & 10.48 & 11.49 & 11.45 \\
2 & 18.76 & 15.90 & 16.26 & 14.98 & 15.89 & 16.36 \\
10 & 22.75 & 19.56 & 20.01 & 20.05 & 20.63 & 20.60 \\
\hline
\end{tabular}

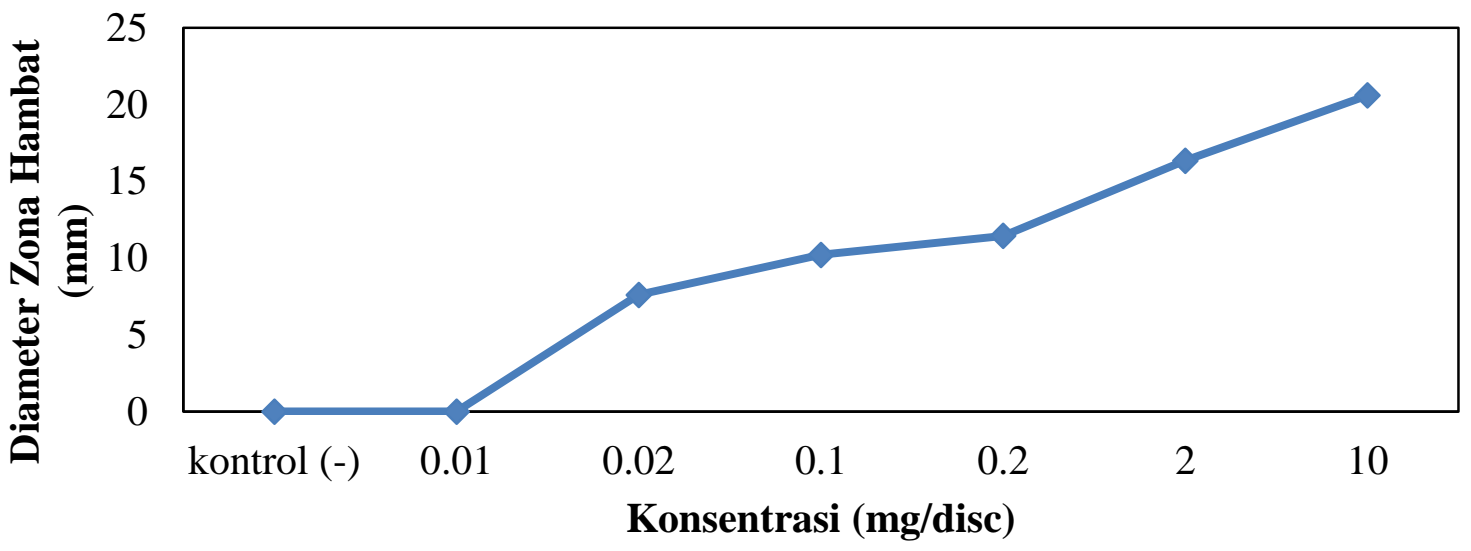

Gambar 3. Kurva perbandingan diameter hambat rata-rata ekstrak metanol akar merung terhadap bakteri Streptococcus mutans.

Dapat dilihat pada tabel 2 dan Gambar 3, bahwa ekstrak metanol akar tumbuhan merung memiliki aktivitas antibakteri terhadap bakteri uji yang digunakan yaitu bakteri gram positif Streptococcus mutans. Hal ini dapat dilihat dari terbentuknya zona hambat pada medium agar dengan berbagai konsentrasi yang digunakan yakni zona hambat dimulai dari konsentrasi 0.02 $\mathrm{mg} /$ disc, $0.1 \mathrm{mg} /$ disc, $0.2 \mathrm{mg} /$ disc, 1 $\mathrm{mg} /$ disc, $2 \mathrm{mg} /$ disc, dan $10 \mathrm{mg} /$ disc, sedangkan pada konsentrasi $0.01 \mathrm{mg} /$ disc tidak terdapat aktivitas antibakteri karena tidak terbentuk zona hambat. Dilihat dari kurva diatas konsentrasi paling tinggi dalam menghambat pertumbuhan bakteri adalah $10 \mathrm{mg} /$ disc.
Hasil analisis data menggunakan SPPS 21 bahwa ekstrak metanol akar merung mempunyai aktivitas yang berbeda nyata $\mathrm{P}<0,05$ dalam menghambat pertumbuhan bakteri Streptococcus mutans.

Zona bening terbentuk karena ekstrak yang ada pada paper disk berdifusi ke agar dan mencegah pertumbuhan bakteri Streptococcus mutans yang ada di daerah itu. Diduga campuran senyawa flavonoid, fenolik, tannin, dan saponin yang bertanggung jawab menghambat pertumbuhan bakteri. Aktivitas flavonoid dalam menghambat pertumbuhan bakteri yaitu dengan menyebabkan kerusakan pada membran sel dan menghambat sintesis makromolekul sel bakteri. ${ }^{10}$ Penghambatan pertumbuhan sel mikroba 
oleh komponen fenol dari rempah-rempah disebabkan kemampuan fenol untuk mendenaturasi protein dan merusak membran sel dengan cara melarutkan lemak yang terdapat pada dinding sel, karena senyawa ini mampu melakukan migrasi dari fase cair ke fase lemak. ${ }^{11}$ Aktivitas tanin dalam menghambat pertumbuhan antibakteri berkaitan dengan kemampuannya untuk berikatan dengan dinding sel bakteri, menghambat pertumbuhan dan aktivitas protease. ${ }^{12}$ Aktivitas saponin dalam menghambat pertumbuhan bakteri adalah dengan mengurangi efisiensi pemanfaatan glukosa dalam mikroorganisme, mempengaruhi pertumbuhan dan proliferasi, mengurangi aktivitas enzim kunci dalam metabolisme fisiologis dan menekan sintesis protein, kemudian menyebabkan kematian sel. ${ }^{13}$

\section{KESIMPULAN}

Berdasarkan hasil penelitian uji antibakteri dari ekstrak metanol akar merung dapat disimpulkan bahwa ekstrak metanol akar tumbuhan merung memiliki aktivitas antibakteri terhadap bakteri uji Streptococcus mutans dimulai dari konsentrasi $0.02 \mathrm{mg} /$ disc dan yang paling aktif dalam menghambat pertumbuhan bakteri paling besar pada masing-masing bakteri uji ada pada konsentrasi 10 mg/disc, sedangkan nilai KHM (Konsentrasi Hambat Minimum) ada pada konsentrasi $100 \mu \mathrm{g}$.

\section{DAFTAR PUSTAKA}

[1]. Agustina, A., Tjahajani A., dan Auerkari E. 2007. Pengaruh Pasta Gigi Mengandung Xylitol terhadap Pertumbuhan Streptococcus mutans Serotip C In Vitro. J Dent 2007; 14 (3): 204-205.

[2]. Simon, Lisa. 2007. The Role of $S$. mutans and Oral Ecologi In The Formation of Dental Caries, LethBridge Under Grad. research Jour., Vol. 2
[3]. Sasea, Altriany., B. S. Lampus, dan Aurelia Supit. 2013. Gambaran Status Kebersihan Rongga Mulut dan Status Gingiva Pada Mahasiswa Dengan Gigi Berjejal. Journal e GIGI (eG), Vol. 1, No. 1, Hlm. 52 58. Program Studi Kedokteran Gigi Fakultas Kedokteran Univ. Sam Ratulangi: Manado.

[4]. RISKESDAS. 2013. Riset Kesehatan Dasar Badan Penelitian dan Pengembangan Kesehatan Kementerian Kesehatan RI Tahun 2013.

[5]. Hermanda, R., Widayat, W., dan Rijai, L. 2016. Aktivitas Antibakteri Ekstrak Metanol Akar Tumbuhan Merung (Coptosapelta tomentosa) Terhadap Bakteri Escherichia coli dan Staphylococcus aureus. Prosiding Seminar Nasional Kefarmasian IV. Fakultas Farmasi Universitas Mulawarman. Samarinda.

[6]. Depkes RI. 1995. Farmakope Indonesia, Edisi 4. Penerbit Departemen Kesehatan RI. Jakarta.

[7]. Harbone, J. B. 1998. Metode Fitokimia. Terjemahan dari Phytochemical Method, oleh Kosasih Padmawinata dan Iwang Sudiro. Penertbit ITB Bandung. Bandung.

[8]. Septyaningsih, D. 2010. Isolasi dan identifikasi komponen utama ekstrak biji buah merah (Pandanus conoideus lamk). Universitas Sebelas Maret. Surakarta.

[9]. Ditjen POM. 1977. Materia Medika Indonesia Jilid 1. Penerbit Direktoral Jenderal Pengawas Obat Dan Makanan. Jakarta.

[10]. Dyozem, J. P., Hamamoto, H., Ngameni, B., Ngadjui, B. T., dan Sekimizu, K. 2013. Antimicrobial Action Mechanism of Flavonoids from Dorstenia species. Drug Discoveries \& Therapeutics, 7(2): 66-72. 
[11]. Ajizah A, Thihana, Mirhanuddin. 2007. Potensi ekstrak kayu ulin (Eusideroxylon zwageri $\mathrm{T}$ et $\mathrm{B}$ ) dalam menghambat pertumbuhan bakteri Staphylococcus aureus secara in vitro. Jurnal Ilmiah. 4(1): 37-42.

[12]. Jones, G. A., McAllister, T. A., Muir, A. D., dan Cheng, K. J. 1994. Effects of Sainfoin (Onobrychis viciifolia scop.) Condensed Tannins on Growth and Proteolysis by Four Strains of Ruminal Bacteria. Appl. Environ. Microbiol, 60 (4):13741378.
[13]. Zhi-hui, Y., Xue-zhi, D., Li-qiu, X., Xiu-quing, X., Sha, X., Shuang, L., dan Xue-mei, L. 2013. Antimicrobial Activity and Mechanism of Total Saponins from Allium chinense. Food Science, 34(15): 75-80. 